\title{
PELESTARIAN LINGKUNGAN MASYARAKAT BADUY BERBASIS KEARIFAN LOKAL
}

\author{
Suparmini, Sriadi Setyawati, dan Dyah Respati Suryo Sumunar \\ FIS Universitas Negeri Yogyakarta \\ e-mail: respatisuryo@yahoo.com
}

\begin{abstract}
Abstrak: Pelestarian Lingkungan Masyarakat Baduy Berbasis Kearifan Lokal. Penelitian ini bertujuan untuk mengetahui dan mengkaji tentang upaya pelestarian lingkungan masyarakat Baduy yang tinggal dan berada di Desa Kanekes, Kecamatan Leuwidamar, Kabupaten Lebak Provinsi Banten. Metode deskriptif kualitatif dilakukan sebagai pendekatan penelitian. Kearifan lokal dikaji sebagai basis dalam penelitian ini, khususnya dalam upaya pelestarian lingkungan pada masyarakat Baduy. Pengumpulan data dilakukan melalui observasi, dokumentasi, dan wawancara dengan beberapa narasumber. Analisis data secara kualitatif melalui, reduksi data, penyajian data, dan pengambilan kesimpulan. Hasil penelitian menunjukkan bahwa, Kehidupan suku Baduy masih sangat tergantung pada alam dan senantiasa menjaga keseimbangan alam. Kearifan lokal masyarakat Baduy dalam mengelola sumberdaya alam antara lain terlihat dari aturan pembagian wilayah menjadi tiga zona, yaitu zona reuma (permukiman), zona heuma (tegalan dan tanah garapan), dan zona leuweung kolot (hutan tua). Hubungan antar aspek kehidupan masyarakat Baduy di Kanekes memiliki integrasi yang sinergis dalam menciptakan kehidupan yang berkelanjutan. Pandangan masyarakat Baduy relatif sama terhadap hubungan antara kehidupan sosial budaya, ekonomi, serta pengelolaan lingkungan. Adat istiadat sebagai bagian dari kearifan lokal masih dipegang dengan sangat kukuh oleh masyarakat Baduy, dan adat istiadat tersebut telah menjadi benteng diri bagi masyarakat Baduy dalam menghadapi modernisasi, termasuk dalam hal melestarikan lingkungannya. Bentuk perilaku pelestarian lingkungan dan konservasi yang dilakukan oleh masyarakat Baduy, antara lain meliputi: (1) sistem pertanian, (2) sistem pengetahuan, (3) sistem teknologi, dan (4) praktik konservasi. Kesemuanya itu dilakukan dengan mendasarkan pada ketentuan adat dan pikukuh yang telah tertanam dalam jiwa dan dilakukan dengan penuh kesadaran oleh seluruh anggota masyarakat Baduy.
\end{abstract}

Kata kunci: pelestarian lingkungan, masyarakat Baduy, kearifan lokal

\begin{abstract}
Continuation of Environment of Society Baduy Base on The Local Wisdom. This research aim to know and study about effort of continuation of environment of society Baduy which omit and reside in the Countryside Kanekes, Sub district Leuwidamar, Regency of Lebak Province Banten. Descriptive method is qualitative conducted as research approach. Local wisdom studied as bases in this research, specially in the effort continuation of environment at society Baduy. Data collecting conducted through observation, documentation, and interview with a few informant. Analysis data qualitative through, data reducing, data presentation, and conclusion intake. Result of research indicate that the, life of Tribe Baduy still very depend on nature and ever balance the nature. Local wisdom of society Baduy in managing experienced resources for example seen from regional division order become three zone, that is zone reuma (settlement), zone heuma (non irrigated dry field and land ground), and fussy zone leuweung (old forest). Relation usher the aspect of life of society Baduy in Kanekes own the integration which synergism in creating going concern life. view of Society Baduy relative of equal to relation among social life of culture, economic, and also environmental management. Mores as part of local wisdom still be holder firm considerably by society Baduy, and the mores
\end{abstract}


have come to the self fortress for society Baduy in face of modernization, included in matter preserve its environment. Behavioral form continuation of environment and conservation conducted by society Baduy, for example covering: (1) agriculture system, (2) knowledge system, (3) technological system, and (4) practice conservation. All the things conducted by relying on rule of custom and pikukuh which have planted in soul and conducted with eyes open by entire or all member of society Baduy.

Keyword: continuation of environment, society of Baduy, local wisdom

\section{PENDAHULUAN}

Dewasa ini, di Indonesia dan negaranegara berkembang lainnya telah muncul pemikiran bahwa keutuhan kawasan pelestarian tidak dapat dipertahankan tanpa menyediakan sumber kehidupan bagi penduduk lokal yang kelangsungan hidupnya sangat tergantung pada sumber daya alam di daerahnya. Untuk memperhatikan kepentingan penduduk lokal dalam upaya pelestarian alam, maka telah dibangun model pendekatan baru, misalnya model Proyek Konservasi dan Pembangunan Terpadu (Integrated Conservation and Development Project-ICDP) atau Sistem Kawasan Lindung Terpadu (Integrated Protected Area SystemsIPAS).

Dalam pengelolaan kawasan konservasi alam, seyogianya selain aspek-aspek biofisik, perlu pula diperhatikan aspek sosial, ekonomi dan budaya masyarakat lokal, termasuk praktik pelestarian kawasan suci atau sakral oleh masyarakat lokal. Sesungguhnya isu tentang pelestarian daerah suci, daerah sakral, atau daerah keramat dalam kaitan pelestarian alam telah mendapat perhatian UNESCO, dengan menjadikannya sebagai kawasan Cagar Biosfer.

Di Indonesia, khususnya daerah Jawa Barat dikenal beberapa daerah yang disakralkan dan disucikan oleh masyarakat lokal, antara lain hutan keramat (HK) di Kampung Dukuh, Garut Selatan; HK di Kampung Kuta dan HK Situ Panjalu Ciamis; HK di Kampung Naga, Tasikmalaya; HK Gunung Halimun Masyarakat Kasepuhan, Sukabumi Selatan, dan HK di Kawasan Baduy, Banten Selatan. Pada umumnya, berbagai kawasan hutan keramat tersebut masih terpelihara cukup baik oleh masyarakat lokal. Padahal berba- gai kawasan hutan di Jawa Barat dan Banten, di luar kawasan hutan keramat tersebut telah banyak yang mengalami kerusakan parah (Iskandar, 2006: 18). Oleh karena itu, berbagai kawasan hutan keramat tersebut mempunyai fungsi penting bagi pelestarian keanekaragaman hayati yang ada di dalamnya.

Kawasan hutan keramat pada masyarakat Baduy di Desa Kanekes, Banten Selatan, merupakan daerah yang paling disakralkan dan dilindungi oleh orang Baduy. Hal tersebut tidak lepas dari sistem kepercayaan animisme yang dianut oleh masyarakat Baduy yaitu Sunda Wiwitan. Inti dari kepercayaan tersebut ditunjukkan dengan ketentuan adat yang mutlak yang disebut juga pikukuh (peraturan adat) dengan konsep tidak adanya perubahan sedikit pun atau tanpa perubahan apapun yang berbunyi lojor teu meunang dipotong, pondok teu meunang disambungan, yang berarti panjang tidak boleh dipotong, pendek tidak boleh disambung. Makna pikukuh itu antar lain tidak mengubah sesuatu, atau dapat juga berarti menerima apa yang sudah ada.

Masyarakat Baduy merupakan salah satu suku di Indonesia yang sampai sekarang masih mempertahankan nilai-nilai budaya dasar yang dimiliki dan diyakininya, ditengahtengah kemajuan peradaban di sekitarnya. Mereka bermukim tepat di kaki pegunungan Kendeng di desa Kanekes, Kecamatan Leuwidamar, Kabupaten Lebak-Rangkasbitung, Banten, berjarak sekitar $40 \mathrm{~km}$ dari kota Rangkasbitung. Wilayah yang merupakan bagian dari Pegunungan Kendeng dengan ketinggian $300-600 \mathrm{~m}$ di atas permukaan laut (dpl) tersebut mempunyai topografi berbukit dan bergelombang dengan kemiring- 
an rata-rata mencapai $45 \%$, yang merupakan tanah vulkanik (di bagian utara), tanah endapan (di bagian tengah), dan tanah campuran (di bagian selatan), suhu udara ratarata $20^{\circ} \mathrm{C}$. Masyarakat Baduy memiliki tanah adat kurang lebih sekitar 5.108 hektar, mereka memiliki prinsip hidup cinta damai, tidak mau berkonflik, serta taat pada tradisi dan hukum adat.

Adat, budaya, dan tradisi masih kental mewarnai kehidupan masyarakat Baduy. Ada tiga hal utama yang mewarnai keseharian mereka, yaitu sikap hidup sederhana, bersahabat dengan alam yang alami, dan spirit kemandirian. Sederhana dan kesederhanaan merupakan titik pesona yang lekat pada masyarakat Baduy. Hingga saat ini masyarakat Baduy masih berusaha tetap bertahan pada kesederhanaannya di tengah kuatnya arus modernisasi di segala segi. Bagi mereka kesederhanaan bukanlah kekurangan atau ketidakmampuan, akan tetapi menjadi bagian dari arti kebahagiaan hidup sesungghuhnya.

Di tengah kehidupan modern yang serba nyaman dengan listrik, kendaraan bermotor, hiburan televisi serta tempat-tempat hiburan lain yang mewah, masyarakat Baduy masih setia dengan kesederhanaan, hidup menggunakan penerangan lilin atau lampu minyak (lampu teplok). Tidak ada sentuhan modernisasi di sana, segala sesuatunya sederhana dan dihasilkan oleh mereka sendiri, seperti makan, pakaian, alat-alat pertanian, dan sebagainya. Meskipun anti modernisasi, mereka tetap menghormati kehidupan modern yang ada di sekitarnya. Kesederhanaan dan toleransi terhadap lingkungan di sekitarnya adalah ajaran utama masyarakat Baduy. Dari kedua unsur tersebut, dengan sendirinya akan muncul rasa gotong royong dalam kehidupan mereka. Tidak ada keterpaksaan untuk mengikuti dan menjaga tradisi kehidupan yang damai oleh mereka. Tidak ada rasa iri satu dengan lainnya karena semuanya dilakukan secara bersama-sama. Kepentingan sosial selalu dikedepankan sehingga jarang dijumpai kepemilikan individu, tetapi menjunjung tinggi asas demokrasi. Tidak ada kesenjangan sosial maupun ekonomi antara individu pada Masyarakat Baduy.

Segala hal yang alami, berhubungan dengan alam adalah sahabat masyarakat Baduy. Hal itu terlihat dari lokasi di mana mereka tinggal. Lingkungan tempat tinggal mereka tidak dijangkau oleh transportasi modern, dan terpencil di tengah-tengah bentang alam pegunungan, perbukitan rimbun, serta hutan, lengkap dengan sungai dan anak sungai, juga hamparan kebun, ladang (huma).

Sebutan 'Baduy' sendiri diambil dari sebutan penduduk luar yang berawal dari peneliti Belanda yang menyamakan mereka dengan Badawi atau Bedouin Arab yang merupakan arti dari masyarakat nomaden. Di samping itu sebutan Baduy pun diperkirakan diambil dari nama gunung dan sungai Baduy yang terdapat di wilayah utara. Tapi suku yang masih memegang teguh adat Sunda ini lebih sering disebut sebagai masyarakat Kanekes karena nama desa tempat tinggal mereka yang bernama Kanekes.

Spirit bertahan hidup dengan kekuatan sendiri diwujudkan dalam gairah dan etos kerja yang tinggi. Berbagai aktivitas kerja khas petani gunung, dari yang ringan hingga yang berat dilakukan dengan ekspresi rela dan gembira. Di Baduy selalu ada pekerjaan, bagi siapapun, laki-laki, perempuan, tua, muda, remaja, dan anak-anak. Mulai umur sepuluh tahun, anak-anak, baik laki-laki maupun perempuan wajib belajar dan berlatih mengerjakan apa saja, membantu dan mencontoh orangtuanya. Bekerja, belajar, dan bermain dilakukan secara bersamasama. Tempatnya bisa dimana saja; rumah, saung, ladang, atau kebun (Erwinantu, 2012:6)

Masyarakat Baduy secara umum telah memiliki konsep dan mempraktikkan pencagaran alam (nature conservation). Misalnya mereka sangat memperhatikan keselamatan hutan. Hal ini mereka lakukan karena mereka sangat menyadari bahwa dengan menjaga hutan maka akan menjaga keterlanjutan ladangnya juga. Lahan hutan yang 
berada di luar wilayah permukiman, biasa mereka buka setiap tahun secara bergilir untuk dijadikan lahan pertanian.

Interaksi antara manusia dan lingkungannya tidak selalu berdampak positif, adakalanya menimbulkan dampak negatif, yakni menimbulkan bencana, malapetaka, dan kerugian-kerugian lainnya. Pada kondisi seperti itu, kearifan lokal yang dimiliki oleh masyarakat dapat meminimalkan dampak negatif yang ada. Demikian pula pada masyarakat Baduy, dengan mengikuti, melaksanakan, dan meyakini pikukuh dari leluhur yang dilakukan secara turun temurun, secara sadar atau tidak sadar, langsung atau tidak langsung, memiliki peranan yang besar terhadap pelestarian lingkungan. Oleh karena itu, berbagai kearifan budaya, pemanfaatan sumberdaya alam secara berkelanjutan pada masyarakat Baduy menarik untuk dikaji.

Pelestarian lingkungan Baduy yang terdiri atas lingkungan alam dan sistem sosial budaya tergantung dari beberapa faktor. Faktor tersebut bersifat eksternal (berasal dari luar komunitas) dan internal (berasal dari dalam komunitas). Gangguan yang merupakan faktor eksternal antara lain adalah ancaman terhadap kelestarian hutan dan pelanggaran atas hak ulayat Baduy. Luas hutan alam yang merupakan leuweng kolot (hutan larangan) terus berkurang. Ancaman tersebut dilakukan oleh penduduk di luar Baduy, antara lain melakukan penebangan hutan, penyerobotan tanah, dan pengambilan ikan di sungai dengan menggunakan racun. Sementara itu, gangguan faktor internal terhadap pelestarian lingkungan Baduy, antara lain adalah pertumbuhan penduduk Baduy yang relatif pesat. Pertambahan penduduk Baduy adalah sekitar 3,7\% per tahun. (Cecep Eka Permana, 2010:134). Pertumbuhan penduduk yang cepat menyebabkan kebutuhan akan sumber daya alam terus meningkat. Namun, karena sumber daya alam seperti lahan pertanian relatif tetap, padahal penggarapan lahan dilakukan terus menerus, maka akan terjadi penurunan kualitas yang terus menerus.
Menurut Saini (Cecep Eka Permana, 2010: 1), kearifan lokal sering dikaitkan dengan masyarakat lokal. Dalam bahasa asing dikonsepsikan sebagai kebijakan setempat (local wisdom), pengetahuan setempat (local knowledge), atau kecerdasan setempat (local genius). Kearifan lokal adalah sikap, pandangan, dan kemampuan suatu komunitas di dalam mengelola lingkungan rohani dan jasmaninya, yang memberikan kepada komunitas itu daya tahan dan daya tumbuh di dalam wilayah dimana komunitas itu berada. Dengan kata lain, kearifan lokal adalah jawaban kreatif terhadap situasi geografispolitis-historis, dan situasional yang bersifat lokal.

Kearifan lokal juga dapat diartikan sebagai pandangan hidup dan pengetahuan serta berbagai strategi kehidupan yang berwujud aktivitas yang dilakukan oleh masyarakat lokal dalam menjawab berbagai masalah dalam pemenuhan kebutuhan mereka, meliputi seluruh unsur kehidupan; agama, ilmu dan teknologi, organisasi sosial, bahasa dan komunikasi, serta kesenian. Mereka mempunyai pemahaman, program, kegiatan, pelaksanaan terkait untuk mempertahankan, memperbaiki, dan mengembangkan unsur kebutuhan dan cara pemenuhannya, dengan memperhatikan sumber daya manusia dan sumber daya alam di sekitarnya.

Kearifan lokal dipandang sangat bernilai dan mempunyai manfaat tersendiri dalam kehidupan masyarakat. Sistem tersebut dikembangkan karena adanya kebutuhan untuk menghayati, mempertahankan, dan melangsungkan hidup sesuai dengan situasi, kondisi, kemampuan, dan tata nilai yang dihayati di dalam masyarakat yang bersangkutan. Dengan kata lain, kearifan lokal tersebut kemudian menjadi bagian dari cara hidup mereka yang arif untuk memecahkan segala permasalahan hidup yang mereka hadapi. Berkat kearifan lokal mereka dapat melangsungkan kehidupannya, bahkan dapat berkembang secara berkelanjutan (sustainable development) (Cecep Eka Permana, 2010: 3). 
Menurut Ife Jim (Cecep Eka Pemana, 2010: 4), kearifan lokal memiliki enam dimensi, yaitu: (1) Dimensi pengetahuan lokal. Setiap masyarakat dimana mereka berada selalu memiliki pengetahuan lokal yang terkait dengan lingkungan hidupnya, (2) Dimensi nilai lokal. Untuk mengatur kehidupan antara warga masyarakat, maka setiap masyarakat memiliki aturan atau nilai-nilai lokal yang ditaati dan disepakati bersama oleh seluruh anggotanya, (3) Dimensi keterampilan lokal. Keterampilan lokal bagi setiap masyarakat dipergunakan sebagai kemampuan bertahan hidup (survival). Keterampilan lokal biasanya hanya cukup dan mampu memenuhi kebutuhan keluarganya masing-masing atau disebut dengan ekonomi subsistensi, (4) Dimensi sumberdaya lokal. Sumberdaya lokal pada umumnya adalah sumberdaya alam. Masyarakat akan menggunakan sumberdaya lokal sesuai dengan kebutuhannya dan tidak akan mengeksploitasi secara besar-besaran atau dikomersialkan. Sumberdaya lokal ini sudah dibagi peruntukannya, seperti hutan, kebun, sumber air, lahan pertanian, dan permukiman. Kepemilikan sumberdaya lokal ini biasanya bersifat kolektif. (5) Dimensi mekanisme pengambilan keputusan lokal. Setiap masyarakat pada dasarnya memiliki pemerintahan lokal sendiri atau disebut pemerintahan kesukuan. Suku merupakan kesatuan hukum yang memerintah warganya untuk bertindak sebagai warga masyarakat. Masing-masing masyarakat mempunyai mekanisme pengambilan keputusan yang berbeda-beda. (6) Dimensi solidaritas kelompok lokal. Suatu masayrakat umumnya dipersatukan oleh ikatan komunal yang dipersatukan oleh ikatan komunikasi untuk membentuk solidaritas lokal. Setiap masyarakat mempunyai media-media untuk mengikat warganya yang dapat dilakukan melalui ritual keagamaan atau acara dan upacara adat lainnya. Masing-masing anggota masyarakat saling member dan menerima sesuai dengan bidang fungsinya masingmasing, seperti dalam solidaritas mengolah tanaman padi, dan kerja bakti gotong royong.
Sebagai bagian dari kebudayaan tradisional, kearifan lokal merupakan warisan budaya. Kearifan lokal hidup dalam domain kognitif, afektif, dan motorik, serta tumbuh menjadi aspirasi dan apresiasi publik. Menurut Geriya (Cecep Eka Permana, 2010: 6), kearifan lokal berorientasi pada (1) keseimbangan dan harmoni manusia, alam, dan budaya; (2) kelestarian dan keragaman alam dan kultur; (3) konservasi sumberdaya alam dan warisan budaya; (4) penghematan sumberdaya yang bernilai ekonomi; (5) moralitas dan spiritualitas.

Masyarakat setempat yang menerapkan cara hidup tradisional di daerah pedesaan, yang nyaris tak tersentuh teknologiumumnya dikenal sebagai masyarakat suku, komunitas asli atau masyarakat hukum adat, penduduk asli atau masyarakat tradisional (Suhartini, 2009:6). Masyarakat setempat seringkali menganggap diri mereka sebagai penghuni asli kawasan terkait, dan mereka biasanya berhimpun dalam tingkat komunitas atau desa. Kondisi demikian dapat menyebabkan perbedaan rasa kepemilikan antara masyarakat asli/pribumi dengan penghuni baru yang berasal dari luar, sehingga masyarakat setempat seringkali menjadi rekan yang tepat dalam konservasi. Di sebagian besar penjuru dunia, semakin banyak masyarakat setempat telah berinteraksi dengan kehidupan modern, sehingga sistem nilai mereka telah terpengaruh, dan diikuti penggunaan barang dari luar. Pergeseran nilaiakan beresiko melemahnya kedekatan masyarakat asli dengan alam sekitar, serta melunturkan etika konservasi setempat.

Masyarakat tradisional pada umumnya sangat mengenal dengan baik lingkungan di sekitarnya. Mereka hidup dalam berbagai ekosistem alami yang ada di Indonesia, dan telah lama hidup berdampingan dengan alam secara harmonis, sehingga mengenal berbagai cara memanfaatkan sumberdaya alam secara berkelanjutan. Di samping itu dalam berperilaku orang akan berpedoman pada berbagai macam hal yang pada hakikatnya mempunyai nilai baik dan buruk serta pada kegiatan yang didasarkan pada 
benar dan salah.

Dalam kearifan lokal juga terwujud upaya pengelolaan sumberdaya alam dan lingkungan yang juga merupakan wujud dari konservasi oleh masyarakat. Berkaitan dengan hal itu, Nababan (1995: 6) mengemukakan: "prinsip-prinsip konservasi dalam pengelolaan sumberdaya alam secara tradisional meliputi: (1) Rasa hormatyang mendorong keselarasan (harmoni) Hubungan manusia dengan alam sekitarnya. Dalam hal ini masyarakat tradisional lebih condong memandang dirinya sebagai bagian dari alam itu sendiri, (2) Rasa memiliki yang eksklusif bagi komunitas atas suatu kawasan atau jenis sumberdaya alam tertentu sebagai hak kepemilikan bersama (communal property resource). Rasa memiliki ini mengikat semua warga untuk menjaga dan mengamankan sumberdaya bersama ini dari pihak luar, (3) Sistem pengetahuan masyarakat setempat (lokal knowledge system) yang memberikan kemampuan kepada masyarakat untuk memecahkan masalah-masalah yang mereka hadapi dalam memanfaatkan sumberdaya alam yang terbatas, (4) Daya adaptasi dalam penggunaan teknologi sederhana yang tepat guna dan hemat (input) energi sesuai dengan kondisi alam setempat, (5) Sistem alokasi dan penegakan aturan-aturan adat yang bisa mengamankan sumberdaya milik bersama dari penggunaan berlebihan, baik oleh masyarakat sendiri maupun oleh masyarakat luar (pendatang). Dalam hal ini masyarakat tradisional sudah memiliki pranata dan hukum adat yang mengatur semua aspek kehidupan bermasyarakat dalam satu kesatuan sosial tertentu, (6) Mekanisme pemerataan (distribusi) hasil panen atau sumber daya milik bersama yang dapat mencegah munculnya kesenjangan berlebihan di dalam masyarakat tradisional. Tidak adanya kecemburuan atau kemarahan sosial akan mencegah pencurian atau penggunaan sumberdaya di luar aturan adat yang berlaku".

\section{METODE}

Penelitian ini merupakan penelitian deskriptif kualitatif, di mana hasil dari pene- litian ini berusaha untuk menjelaskan secara rinci keadaan yang ada di lapangan. Dalam penelitian kualitatif, teori dan sumber data dapat berkembang di lapangan.

Penduduk Kampung (masyarakat) Baduy pada umumnya menjadi subjek dalam penelitian ini. Beberapa narasumber atau key informan diperlukan dalam pemerolehan data dan informasi. Para informan tersebut adalah Sekretaris Desa Kanekes, Ketua RT, Tokoh Masyarakat, dan Tokoh Adat. Objek yang diamati dalam penelitian ini adalah: (1) Alam dan lingkungan masyarakat Baduy, (2) Kearifan lokal masyarakat Baduy, (3) Adat istiadat masyarakat Baduy, (4) Pola kehidupan sosial budaya dan ekonomi masyarakat Baduy, (5) Upaya konservasi dan pelestarian lingkungan masyarakat Baduy

Dalam pengumpulan data penelitian, digunakan teknik observasi, dokumentasi, dan wawancara. Teknik observasi yang dilakukan yaitu observasi terstruktur di mana peneliti telah menyiapkan pedoman observasi. Instrumen observasi menggunakan daftar isian atau chek list. Metode dokumentasi digunakan untuk melengkapi data dan informasi lain yang diperoleh instansi terkait atau sumber referensi lain, termasuk studi pustaka. Lembar dokumentasi digunakan sebagai instrumen dalam penelitian ini. Proses wawancara dilakukan dengan bertatap muka secara langsung (face to face) dengan nara sumber atau key informan. Pedoman wawancara digunakan sebagai instrumen untuk memudahkan dalam proses wawancara dengan nara sumber atau key informan. Analisis data dilakukan menggunakan tiga alur kegiatan yang terjadi secara bersamaan yaitu: reduksi data, penyajian data, dan penarikan kesimpulan/verifikasi.

\section{HASIL DAN PEMBAHASAN}

Secara geografis wilayah Baduy terletak pada koordinat $6^{\circ} 27^{\prime} 27^{\prime \prime} \mathrm{LS}-6^{\circ} 30^{\prime} 0^{\prime \prime} \mathrm{LS}$ dan $108^{\circ} 3^{\prime} 9^{\prime \prime}$ BT $-106^{\circ} 4^{\prime} 55^{\prime \prime}$ BT, dan secara administratif wilayah Baduy termasuk dalam wilayah Desa kanekes, Kecamatan Leuwidamar, Kabupaten lebak, Provinsi Banten. Wilayah Baduy terdiri atas beberapa 
kampung yang secara adat terdiri atas Baduy Tangtu dan Baduy Panamping. Kampung yang merupakan Baduy Tangtu terdiri atas kampung Cibeo, Cikartawana, dan Cikeusik yang merupakan wilayah Baduy Dalam, dan kampung yang merupakan Baduy Panamping atau wilayah Baduy Luar terdiri atas 54 kampung. Untuk sampai ke wilayah Baduy, dapat melewati ibukota Kabupaten Rangkasbitung, kemudian menuju ke Kecamatan Leuwidamar. Wilayah Baduy terletak sekitar $13 \mathrm{~km}$ dari kota Kecamatan Leuwidamar, sekitar 38 km dari kota Rangkasbitung. Perjalanan menggunakan kendaraan menuju wilayah Baduy akan berakhir di Desa Ciboleger, Kecamatan Leuwidamar.

Topografi daerah Baduy terdiri atas bukitbukit dengan kemiringan lereng hingga mencapai rata-rata $45 \%$, sedangkan keadaan tanahnya dapat dibagi menjadi tiga bagian, yaitu pegunungan vulkanik disebelah utara, endapan tanah pegunungan dibagian tengah, dan dibagian selatan berupa campuran pegunungan vulkanik dengan endapan yang menjulang tinggi. Luas wilayah Baduy meliputi 5.101,85 ha, secara umum dibagi menjadi tiga macam tata guna lahan, yakni lahan usaha pertanian, lahan hutan tetap, dan permukiman. Lahan usaha pertanian merupakan bagian terbesar dalam penggunaan lahan di wilayah Baduy, yakni seluas $2.585,29$ ha atau 50,67\%. Lahan ini terdiri atas lahan yang ditanami/diusahakan seluas 709,04 ha dan lahan yang tidak ditanami (bera) seluas 1.876,25 ha. Lahan permukiman merupakan bagian yang terkecil, hanya meliputi 24,50 ha atau 0,48\%. Adapun sisanya seluas $2.492,06$ ha atau $48,85 \%$, merupakan hutan tetap sebagai hutan lindung yang tidak boleh digarap untuk dijadikan lahan pertanian.

\section{Sistem Pemerintahan}

Ada dua sistem pemerintahan yang digunakan oleh masyarakat Baduy, yaitu struktur pemerintahan nasional yang mengikuti aturan negara Indonesia dan struktur pemerintahan adat yang mengikuti adat istiadat yang dipercayai oleh masyarakat. Kedua sistem pemerintahan tersebut digabungkan dan dibagi perannya sedemikian rupa sehingga tidak ada benturan dalam menjalankan tugasnya. Seluruh masyarakat Baduy paham dan saling menghargai terhadap kedua sistem tersebut, sehingga mereka tahu harus kemana jika ada urusan atau permasalahan yang dihadapi dalam kehidupan sehari-hari (Feri Prihantoro, 2006: 6)

Dalam sistem pemerintahan nasional penduduk di Kanekes ini dipimpin oleh Jaro Pamarentah. Secara administratif jaro pamarentah ini bertanggung jawab terhadap sistem pemerintahan nasional yang ada di atasnya yaitu camat, tetapi secara adat bertanggung jawab kepada pemimpin tertinggi adat yaitu Puun. Dalam menjalankan tugasnya dibantu oleh sekretaris desa yang berasal dari luar Kanekes dan dua orang pembantu lain yang disebut Pangiwa dari dalam Kanekes. Jaro pemarentah merupakan penyeimbang antara sistem pemerintah nasional dengan sistem adat di Baduy selain itu juga berfungsi sebagai penghubung antara Baduy dengan dunia luar.

Pemilihan pemimpin pemerintahan nasional ini dilakukan dengan kesepakatan antara Puun dengan camat sebagai atasan dari sistem nasional. Struktur pemerintahan masyarakat Baduy, dapat diperhatikan pada Gambar 1.

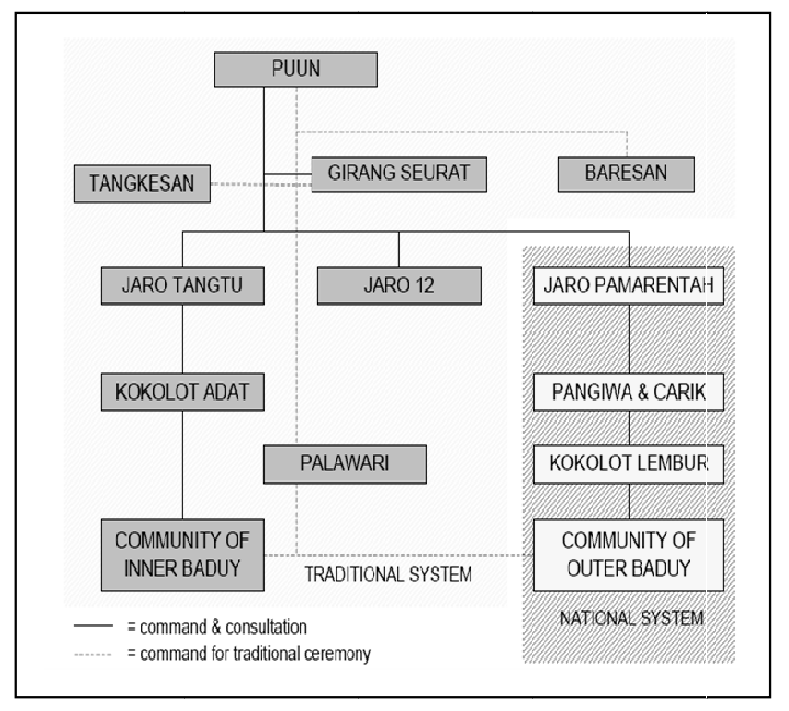

Gambar 1. Struktur Pemerintahan Baduy (sumber: Feri Prihantoro, 2006:7) 
Puun dianggap pemimpin tertinggi untuk mengatasi semua aspek kehidupan di dunia dan mempunyai hubungan dengan karuhun. Dalam kesatuan Puun tersebut terdapat senioritas yang ditentukan berdasarkan alur kerabat bagi peranan tertentu dalam pelaksanaan adat dan keagamaan Sunda Wiwitan. Puun memiliki kekuasaan dan kewibawaan yang sangat besar, sehingga para pemimpin yang ada di bawahnya dan warga masyarakat Baduy tunduk dan patuh kepadanya.

Bagi orang Baduy seorang pemimpin dalam pamarentahan berasal dari keturunan para Puun yang artinya, satu sama lain terikat oleh garis kerabat. Dalam konteks itu, ciri penting dalam pamarentahan Baduy, terletak pada diferensiasi peran dan pembagian jabatan yang terpisahkan melalui struktur sosial, namun semuanya terikat oleh satu hubungan kerabat yang erat. Perbedaan peran yang mendasar antara para pemimpin yang disebut puun dan yang disebut para jaro, adalah pada tanggung jawab yang berurusan dengan aktivitasnya, karena para puun berurusan dengan dunia gaib, sedangkan para jaro bertugas menyelesaikan persoalan duniawi.

\section{Pendidikan}

Pendekatan pendidikan di Baduy adalah nonformal yang dilakukan di rumah-rumah maupun di lapangan secara langsung. Tidak ada bangunan sekolah formal di sana, meskipun $40 \%$ masyarakanya dapat membaca dan menulis. Mereka memiliki sistem pendidikan sendiri, dimana bagi anak-anak sebelum usia 10 tahun dibimbing oleh orang tua masing-masing. Setelah usia 10 tahun, mereka belajar mengenai norma dan aturan yang berlaku di Baduy dengan berkelompok kecil. Kelompok-kelompok tersebut didasarkan pada kedekatan rumah mereka, dan dibimbing oleh seorang pemimpin atau jaro yang ada di lingkungan dekat mereka. Umumnya tempat belajar mereka di rumah pemimpin mereka yang memiliki tempat luas, selain itu juga pelajaran lebih banyak dilakukan di alam secara langsung (Feri Prihantono, 2006: 9).
Materi atau substansi pendidikan yang diajarkan oleh mereka secara turun temurun pada dasarnya adalah sesuai dengan kebutuhan hidup saja. Aspek aturan hidup, ekonomi, sosial, serta lingkungan merupakan materi pelajaran yang diajarkan bagi semua masyarakat. Belajar aturan hidup merupakan dasar pelajaran yang harus diketahui semua masyarakat. Hal-hal yang baik dan buruk menurut mereka diajarkan secara turun temurun. Aturan hidup merupakan payung dari seluruh aktivitas. Aspek ekonomi yang diajarkan hanya sederhana, yaitu belajar bercocok tanam dengan tetap menjaga keseimbangan alam. Semua laki-laki Baduy dapat bercocok tanam sesuai dengan cara bercocok tanam mereka. Perempuan baduy belajar menenun pakaian dan membuat gula aren. Pengetahuan sosial masyarakat diberikan untuk memahami struktur adat serta ritual-ritual yang harus dijalankan.

Pelajaran mengenai menjaga kelestarian lingkungan ditujukan untuk tetap menjaga keutuhan bentuk alam. Mereka paham titik-titik mana yang tidak boleh dimanfaatkan dan tempat mana yang dapat dimanfaatkan. Untuk menjaga kelestarian air sungai, bahkan mereka diajarkan untuk tidak menggunakan sabun serta pasta gigi, karena dapat mencemari air sungai. Untuk menjaga kebersihan mereka menggunakan bahan-bahan alami dari tumbuhan sebagai pengganti sabun dan pasta gigi.

Pendidikan nonformal yang diajarkan sangat sederhana sekali, hanya untuk memenuhi kebutuhan hidup saja. Dituturkan oleh salah satu Jaro (pemimpin) mereka bahwa mereka mendidik masyarakatnya bukan untuk menjadi pintar tetapi untuk menjadi jujur. Mereka berpikir bahwa orang pintar identik dengan modern, sehingga orang pintar berkeinginan untuk melakukan perubahan di lingkungan Baduy. Sedangkan orang jujur lebih bisa mematuhi aturan yang ada di lingkungan Baduy dan cenderung mengikuti aturan tersebut. Sumber ilmu yang diajarkan diambil dari fenomena alam yang terjadi disana. Alam merupakan sum- 
ber ilmu yang disarikan oleh orang-orang tua dan diturunkan kepada anak-anak mereka. Prinsip dengan perubahan sekecil-kecilnya menjadi landasan pelajaran yang diajarkan kepada anak-anak.

\section{Aktivitas Ekonomi}

Aktivitas utama masyarakat Baduy untuk menunjang kehidupan perekonomiannya adalah dengan bertani. Mereka menggunakan sistem perladangan dalam aktivitas pertaniannya. Menurut masyarakat Baduy sistem berladang yang mereka kerjakan sesuai dengan kepercayaan serta ideologi hidup mereka, yaitu untuk tidak membuat perubahan secara besar-besaran pada alam, karena justru akan menimbulkan ketidakseimbangan alam. Dengan sistem berladang mereka tidak melakukan perubahan bentuk alam, karena mereka menanam mengikuti alam yang ada. Mereka menanam padi dan tumbuhan lainnya sesuai dengan kontur lereng dan mereka tidak membuat terasering. Sistem pengairan tidak menggunakan irigasi teknis, tetapi hanya memanfaatkan hujan yang ada. Ada larangan penggunaan air sungai atau mata air untuk mengairi sawah karena ada anggapan pada masyarakat Baduy bahwa membelokkan arah sungai akan merusak keseimbangan alam. Pelaku utama aktivitas ekonomi masyarakat Baduy adalah laki-laki. Namun, perempuan juga berpartisipasi dalam bidang pertanian walaupun sifatnya hanya membantu.

Larangan-larangan yang harus dipatuhi dalam pertaniannya adalah sebagai berikut:

1. Dilarang menggunakan cangkul saat mengolah tanah,

2. Dilarang menanam singkong

3. Dilarang menggunakan bahan kimia untuk memberantas hama. Pemberantasan hama dan pemupukan tanaman dilakukan secara tradisional,

4. Dilarang pergi ke ladang pada hari Senin, Kamis, dan Sabtu

5. Dilarang membuka ladang di Leuweng atau hutan tutupan dan dilarang membuka lahan di hutan kampung.
Hasil pertanian suku Baduy ada yang dijual dan ada yang hanya untuk keperluan pribadi. Hasil pertanian yang berupa padi hanya untuk kepentingan sendiri, mereka tidak menjualnya. Biasanya setelah panen padi dikeringkan langsung dimasukan ke dalam lumbung padi yang disebut Leuit. Lumbung padi (leuit) terbuat dari anyaman bambu yang dirangkai dengan kayu-kayu besar dan beratapkan kirai (sabut kelapa). Setiap keluarga Baduy memiliki satu atau lebih leuit. Padi yang disimpan di lumbung dimanfaatkan untuk kebutuhan pangan sehari-hari dan lebih diutamakan untuk digunakan pada saat upacara adat, seperti pernikahan atau khitanan.

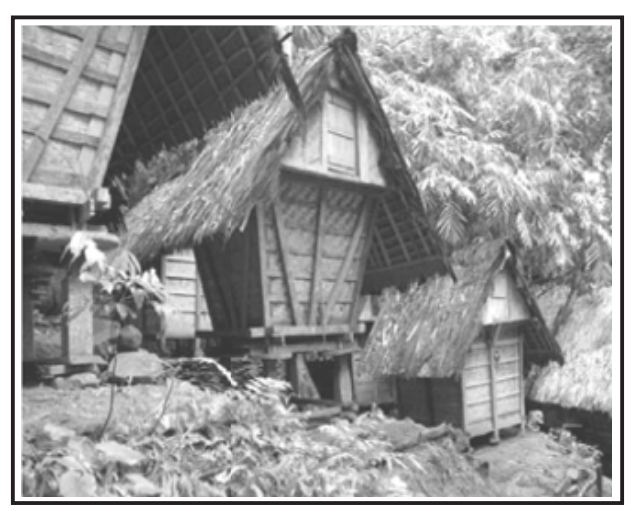

Gambar 2. Lumbung padi (Leuit)

Leuit merupakan milik perorangan bukan milik komunitas atau kelompok. Kebutuhan padi untuk hidup sehari-hari, maupun untuk upacara-upacara telah direncanakan bersama sehingga tidak ada keluarga yang kekurangan maupun kelebihan persediaan padi di rumah. Selain itu masyarakat Baduy tidak dapat seenaknya membuka leuit tanpa seijin pemimpin adat.

\section{Pengelolaan Lingkungan Baduy}

Kondisi lingkungan di desa Kanekes tempat masyarakat Baduy tinggal, memiliki kualitas yang baik yang ditandai dengan kekayaan kenakeragaman hayati yang masih tinggi. Banyak jenis flora dan fauna yang ada di Baduy tidak ditemukan di wilayah lain. Beberapa satwa yang hidup di sana tergolong liar dan langka sehingga dilindungi oleh pemerintah Indonesia. Kemandirian hidup 
mereka menciptakan interaksi masyarakat dan lingkungan yang sangat erat dan saling tergantung.

Secara umum masyarakat Baduy membagi wilayah Kanekes menjadi tiga zona yaitu zona bawah, zona tengah, dan zona atas. Wilayah di lembah bukit yang relatif datar merupakan zona bawah digunakan oleh masyarakat Baduy sebagai zona permukiman. Masyarakat Baduy menamakan zona ini sebagai zona "dukuh lembur" yang artinya adalah hutan kampung. Mereka mendirikan rumah di zona ini secara berkelompok. Rumah adat masyarakat Baduy berbentuk panggung sederhana dan tradisional. Material yang digunakan didapat dari alam disekitar mereka, seperti kayu untuk tiang, bambu untuk dinding dan daun kelapa untuk atapnya. Permukiman mereka berada di ketinggian $250 \mathrm{~m} \mathrm{dpl}$, dengan daerah terendah pada $150 \mathrm{~m} \mathrm{dpl} \mathrm{sedangkan} \mathrm{yang}$ tertinggi sampai dengan $400 \mathrm{~m}$ dpl (di atas permukaan laut).

Zona kedua atau zona tengah berada di atas hutan kampung, lahan ini digunakan sebagai lahan pertanian intensif, seperti ladang kebun dan kebun campuran. Cara berladang mereka masih tradisional yaitu dengan membuka hutan-hutan untuk digunakan sebagai lahan pertanian dan kebun. Hutan yang dibuka untuk ladang merupakan jenis hutan sekunder atau hutan produksi.
Lahan untuk berladang tersebut digunakan selama satu tahun, setelah itu lahan dibiarkan untuk menjadi hutan kembali minimal 3 tahun.

Zona ketiga atau zona atas merupakan daerah di puncak bukit. Wilayah ini merupakan daerah konservasi yang tidak boleh dibuat untuk ladang, hanya dapat dimanfaatkan untuk diambil kayunya secara terbatas. Masyarakat Baduy menyebut kawasan ini sebagai "leuweung kolot" atau "leuweung titipan" yang artinya hutan tua atau hutan titipan yang harus dijaga kelestariannya. Mereka sangat patuh terhadap larangan untuk tidak masuk ke wilayah hutan tua tanpa seizin petinggi adat.

Dengan kawasan hutan lindung atau yang disebut mereka hutan tua, maka daerah Baduy memiliki keanekaragaman hayati yang cukup tinggi. Kondisi tersebut secara ekologi akan menciptakan keseimbangan alam dan memberikan keuntungan lain seperti sumber daya plasma nutfah yang dapat dikembangkan untuk pembudidayaan dan penyilangan tanaman di masa yang akan datang. Adanya vegetasi yang beraneka ragam dapat menjaga iklim setempat, menghindari pemanasan global, melindungi dari angin kencang, terik matahari, perlindungan satwa liar, mencegah bahaya erosi, dan kelestarian lingkungan lainnya.

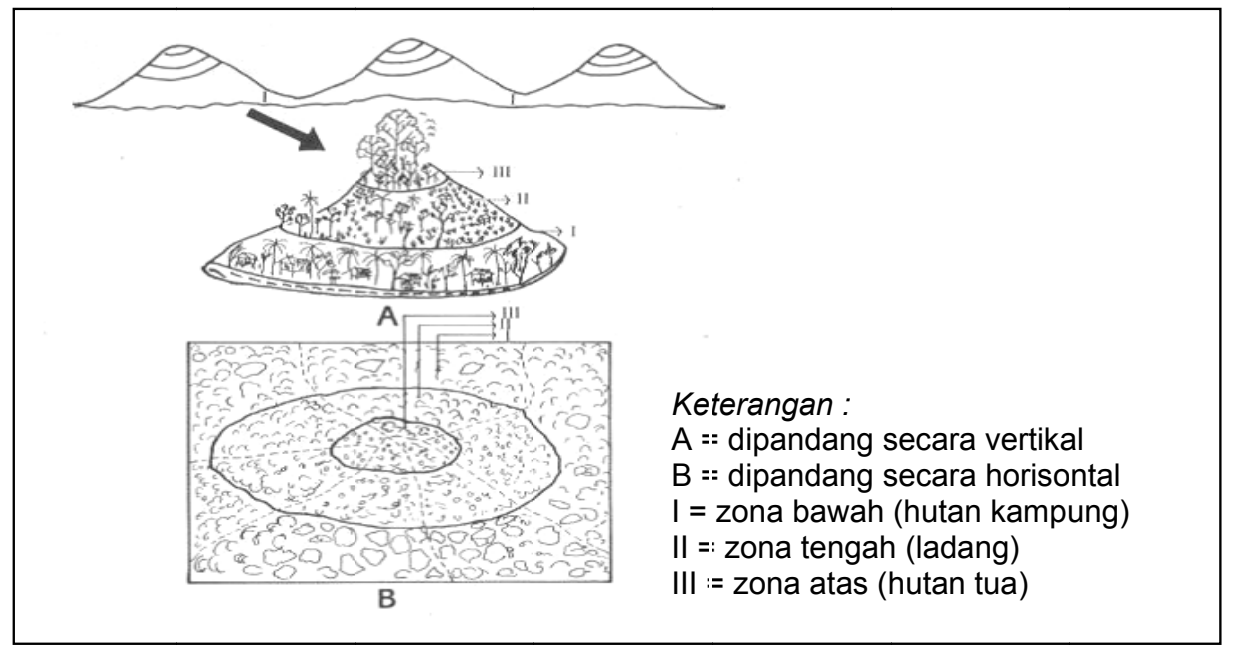

Gambar 3. Pembagian Zona Wilayah Baduy (sumber: Johan Iskandar, 1998, Feri Prihantoro 2006) 
Masyarakat Baduy mengenal konsep tentang hutan, gunung, dan bukit. Menurutnya, ada perbedaan dan persamaan antara ketiga konsep tersebut. Dalam bahasa setempat, hutan disebut dengan leuweung yang berarti banyak pohon yang besar. Bukit disebut monggor yang berarti tempat yang tinggi meskipun tidak terdapat pohon-pohon, dan gunung yang berarti tempat yang tinggi dan terdapat pohon-pohon besar dan tua. Dengan demikian menurut persepsi masyarakat Baduy, hutan bisa terdapat di gunung atau bukit atau bahkan di tempat yang rendah sekalipun.

Hutan dapat dibedakan berdasarkan fungsinya dan letaknya. Berdasarkan fungsinya, hutan terbagi menjadi tiga jenis, yaitu hutan larangan, hutan dudungusan, dan hutan garapan. Hutan larangan adalah hutan lindung yang tidak boleh dimasuki oleh sembarang orang, bahkan oleh orang Baduy atau pimpinan adat sekalipun. Hutan dudungusan adalah hutan yang dilestarikan karena berada di hulu sungai, atau di dalamnya terdapat tempat keramat atau leluhur Baduy, dan hutan garapan adalah hutan yang dapat dimanfaatkan sebagai ladang atau huma.

Hutan larangan berada di sebelah selatan permukiman Baduy tangtu, berada pada lokasi yang paling dalam dan paling tinggi dari kawasan hutan di Baduy. Di dalamnya terdapat kekayaan berbagai jenis tegakan pohon kayu tinggi dengan tajuknya yang rindang, kemudian tanaman keras dan pohon-pohon di bawahnya. Palem-paleman, paku-pakuan, rerambatan, semak perdu, lelumutan, dan tanaman rendah lainnya menyelimuti lantai hutan. Beragam satwa, serangga, dan mikro organisme melengkapi ekosistem hutan. Semakin rapat hutan, semakin kaya menyimpan potensi cadangan air dan kekayaan keanekaragaman hayati. Ini dihormati sebagai biangnya sumber daya hutan yang menafkahi, memasok nutrisi hutan-hutan yang ada di tempat lebih bawah, kebun-kebun, ladang-ladang, hingga pekarangan-pekarangan di sekitar rumah. Dari hutan larangan inilah mata air Sungai
Ciujung dan Cisemeut berawal mengalirkan berkah tak ternilai hingga jauh sampai ke laut.

Hutan larangan Baduy diperlakukan istimewa, dijaga keutuhannya, dirawat kesehatannya. Siapapun dilarang memasukinya, tidak diperkenankan mengusiknya, mengambil sesuatu darinya, bahkan sehelai daun, sepucuk ranting, atau setetes madu pun tidak boleh diambil darinya. Ini adalah hutan larangan, bukan karena angker atau keramat, namun karena masyarakat Baduy sangat menghormati dan menghargai alam atas dasar pemahaman terhadap potensi yang dikandungnya.

Hutan lindung. Pemahaman dasarnya seperti hutan larangan, yaitu harus dijaga keutuhan dan kesehatannya. Potensi aslinya tidak terganggu dan tetap terjaga. Bedanya, di hutan lindung ini masyarakat Baduy yang ada di sekitarnya boleh memanfaatkan dan mengambil hasil hutan lindung secara terbatas.

Hutan garapan. Tampilan fisiknya tidak sama seperti hutan dalam pengertian konvensional. Hutan garapan adalah areal hutan yang difungsikan sebagai ladang atau huma. Semacam lahan abadi untuk tanaman tumpang sari, atau tanaman pangan, yaitu padi dan komoditas kebun.

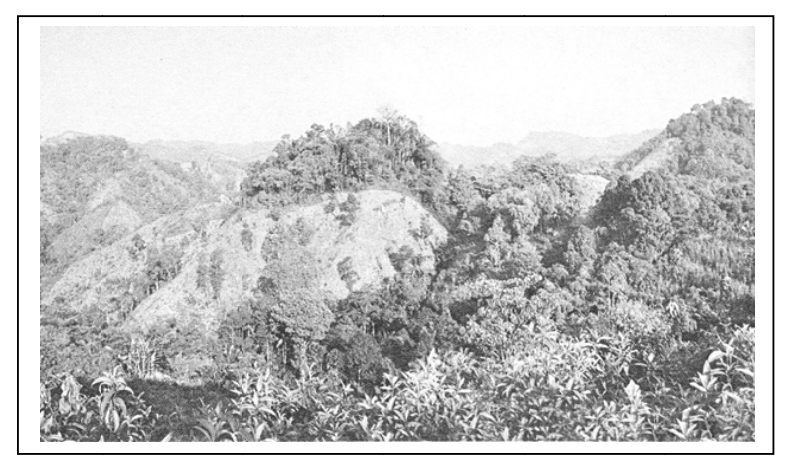

Gambar 4. Lingkungan Alam Baduy dengan

Huma di Lereng Perbukitan dan Hutan Lindung di Puncaknya.

Masyarakat Baduy menganggap bahwa wilayah mereka adalah sebagai inti jagat, dianggap memiliki hak untuk tetap terpeliharan dan tidak terganggu oleh perobahan, karena gangguan itu akan membuat ketidak- 
seimbangan alam semesta termasuk diri mereka sendiri. Orang Baduy memandang alam jagat raya ini sebagai 'satangkarak ning langit, satungkab ning lemah'. Kewajiban orang Baduy bagi taneuh larangan adalah memeliharanya sebaik mungkin sesuai dengan kehendak atau pesan karuhun (nenek moyang).

Pikukuh atau adat dan norma bukan hanya acuan segala perilaku mereka, tetapi juga pedoman serta sekaligus kontrol sosial terhadap perilaku mereka. Orang Baduy menganggap tanah atau lahan sebagai ambu atau ibu, tanah ialah ambu rarang, bagian atas dari tanah atau langit ialah ambu luhur, sedangkan dunia tempat manusia hidup merupakan buana tengah yang dikuasai oleh ambu tengah. Rasa hormat terhadap lahan disetarakan dengan ibu, menunjukkan ikatan erat sebagaimana layaknya hubungan ibu dengan anak-anaknya. Ambu adalah segala sumber kehidupan kepada manusia, dan sumber pula bagi tiga buana, buana luhur, buana tengah, dan buana handap.

\section{Ketentuan Adat sebagai Kearifan Lokal yang Diterapkan pada Masyarakat Baduy}

Masyarakat Baduy percaya bahwa mereka adalah orang yang pertama kali diciptakan sebagai pengisi dunia dan bertempat tinggal di pusat bumi. Segala gerak laku masyarakat Baduy berpedoman kepada buyut karuhun (ketentuan adat). Seseorang tidak berhak dan tidak boleh melanggar dan mengubah tatanan kehidupan yang telah ada dan sudah berlaku turun temurun.

Puun adalah pimpinan tertinggi masyarakat Baduy. Dalam kehiduapnnya, puun adalah pimpinan tertinggi adat Baduy, merupakan keturunan batara serta dianggap sebagai penguasa agama Sunda Wiwitan yang harus ditaati segala perintah dan perkataannya. Rukun agama sunda wiwitan (rukun Baduy) yang terdiri dari: ngukus, ngawalu, muja, ngalaksa, ngalanjak, ngapundayan, dan ngareksakeun sasaka pusaka, harus ditaati oleh seluruh masyarakat Baduy (Gunggung Senoaji, 2011:17). Pikukuh karuhun harus ditaati oleh masyarakat Baduy dan masyarakat luar yang sedang berkunjung ke Baduy. Ketentuan-ketentuan itu di antaranya sebagai berikut.

1. Dilarang mengubah jalan air, misalnya membuat kolam ikan, mengatur drainase, dan membuat irigasi. Oleh karena itu, sistem pertanian padinya adalah padi ladang. Pertanian padi sawah dilarang di komunitas Baduy.

2. Dilarang mengubah bentuk tanah, misalnya menggali tanah untuk membuat sumur, meratakan tanah untuk permukiman, dan mencangkul tanah untuk pertanian.

3. Dilarang masuk hutan titipan (leuweung titipan) untuk menebang pohon, membuka ladang, atau mengambil hasil hutan. Kawasan larangan dan perlindungan tidak dapat dialihfungsikan untuk kegiatan apapun.

4. Dilarang menggunakan teknologi kimia, misalnya menggunakan pupuk, obat pemberantas hama, mandi menggunakan sabun, pasta gigi, mencuci menggunakan detergent, atau meracun ikan.

5. Dilarang menanam tanaman budi daya perkebunan, seperti kopi, kakao, cengkeh, kelapa sawit.

6. Dilarang memelihara binatang ternak berkaki empat, seperti sapi, kambing, kerbau.

7. Dilarang berladang sembarangan. Berladang harus sesuai dengan ketentuan adat.

8. Dilarang menggunakan sembarang pakaian. Ditentukan adanya keseragaman dalam berpakaian. Baduy Dalam berpakaian putih-putih dengan ikat kepala putih, Baduy Luar berpakaian hitam atau biru gelap dengan ikat kepala hitam atau biru gelap.

Buyut dan pikukuh karuhun dilafalkan dengan bahasa sunda kolot dalam bentuk ujaran yang disampaikan pada saat upacaraupacara adat atau akan diceriterakan oleh orang tua kepada anaknya. Ujaran-ujaran tersebut dinggap sebagai prinsip hidup masyarakat Badu, di antaranya adalah: 


\author{
... Pondok teu meunang disambung \\ Lojor teu meunang dipotong \\ Nagara tilupuluh tilu \\ Pencar salawe nagara \\ Kawan sawidak lima \\ Rukun garapan dua welas \\ Mipit kudu amit \\ Ngala kudu menta \\ Ngadedag kudu beara \\ Ngali cikur kudu matur \\ Ulah goroh ulah linyok \\ Ngadeg kudu sacekna \\ Ulah sirik ulah pidik \\ Ulah ngerusak bangsa jeung nagara \\ Gunung teu meunang dilebur \\ Lebak teu meunang dirusak \\ Arey teu meunang diteuteuk \\ Cai teu meunang dituba...
}

Artinya:

... Pendek tidak boleh disambung
Panjang tidak boleh dipotong
Nagara tiga puluh tiga
Terbagi dua puluh lima negara
Sungai enam puluh lima
Warga dua belas yang mengolah dunia
Panen harus minta ijin
Ngambil harus meminta
Berbuat harus memberi tahu
Ngambil kencur harus bicara
Jangan banyak omong, jangan berbohong
Pendirian harus tegas
Jangan sirik jangan dengki
Jangan merusak bangsa dan negara
Gunung tidak boleh dihancurkan
Lembah tidak boleh dirusak
Rerambatan tidak boleh ditebas
Sumber air dan sungai tidak boleh dituba..

Sumber: Gungung Senoaji (2011:18)

Ujaran-ujaran tersebut mengandung arti bahwa lingkungan alam tidak boleh dirusak, tata guna lahan tidak boleh dialihfungsikan untuk kepentingan ekonomi. Kawasan yang berfungsi sebagai kawasan perlindungan harus tetap dipertahankan keberadaannya.

Masyarakat Baduy adalah masyarakat yang menutup diri dari budaya luar. Masyarakat Baduy adalah masyarakat yang dikenal mempunyai otoritas penuh dalam mengatur lingkungan alam dan adat istiadatnya. Masyarakat Baduy tinggal dan hidup di sekitar pegunungan, diantara rimbunan pohon, tanah perbukitan, lereng gunung selama berabad abad lamanya. Mereka mendiami tanah dan hidup di dalam adat tanpa banyak terganggu oleh derasnya modernisasi. Alam yang damai dan kesederhanaan menjadi sahabat dan cara hidup mereka. Para penghuninya menjaga dan melindungi dengan baik lingkungan alamnya, tidak saling menggusur. Semua yang dilakukan seperti menebang, mencabut dan memotong tanaman menggunakan aturan-aturan adat masyarakat Baduy, mereka akrab seperti menyatu dengan lingkungannya, semua tumbuh dan berkembang berdampingan. Hal-hal yang demikian merupakan salah satu kearifan lingkungan masyarakat Baduy yang diwujudkan dengan dipahami, dikembangkan, dipedomani dan diwariskan secara turun temurun oleh komunitas masyarakatnya. Sikap dan perilaku penyimpangan dalam kearifan lingkungan dianggap penyimpangan, tidak arif, merusak, mengganggu, sehingga masyarakat yang tidak mematuhi ketentuan karuhun dianggap mengganggu kelestarian lingkungan alam sekitarnya. Kearifan lokal telah tertanam kuat pada masyarakat Baduy.

\section{Konservasi dan Pelestarian Lingkungan Berbasis KearifanLokal MasyarakatBaduy}

Cara hidup tradisional masyarakat Baduy yang sederhana dan penuh toleransi lebih melihat kehidupan jauh kedepan, sehingga tetap menjaga keberlanjutan hidupnya. Proteksi terhadap lingkungan ditujukan untuk mempertahankan kehidupan mereka supaya tetap utuh dan dapat memenuhi kebutuhan hidup sendiri. Pandangan mereka dalam kelestarian lingkungan, sama dengan pemikiran dalam pembangunan berkelanjutan dimana mereka beranggapan bahwa kerusakan lingkungan atau perubahan ter- 
hadap bentuk lingkungan akan mengancam sumber kehidupan mereka yang berakibat dengan kelaparan dan kekurangan secara ekonomi lainnya. Kehancuran kehidupan akibat kerusakan lingkungan akan memicu kepunahan suku Baduy. Oleh sebab itu mereka juga melarang bahkan melawan pihak luar yang berusaha merusak lingkungan mereka.

Untuk memproteksi lingkungan dari pengaruh dari luar banyak upaya yang dilakukan mereka dari yang bersifat represif maupun preventif. Beberapa usaha preventif yang selama ini dilakukan adalah dengan tidak menerima bantuan pembangunan dari pihak mana pun yang diperkirakan dapat merusak kondisi lingkungan atau tatanan sosial mereka. Selain itu mereka juga terus mendesak pemerintah baik lokal maupun nasional untuk menjadikan kawasan mereka sebagai kawasan yang dilindungi dan didukung dengan peraturan yang diterbitkan oleh pemerintah sehingga mengikat bagi orang di luar Baduy. Dalam kaitannya dengan usaha represif mereka secara tegas langsung menindak siapa saja yang berusaha merusak lingkungan mereka.

Untuk mengendalikan penggunaan lahan oleh masyarakat, di Baduy tidak ada kepemilikan lahan. Lahan disana merupakan tanah adat yang digunakan secara bersamasama. Di wilayah Baduy Dalam tidak ada sistem jual beli maupun sewa menyewa lahan, yang ada adalah kepemilikan tanaman. Tanaman menjadi milik orang yang menanam, sementara lahan tetap menjadi milik adat. Dengan sistem seperti itu adat dapat mengendalikan lahan dan peruntukannya. Lahan-lahan yang dapat digunakan sebagai ladang pertanian digunakan secara bergiliran oleh keluarga-keluarga disana. Untuk wilayah Baduy Luar ada sistem sewa menyewa lahan, tetapi tidak ada sistem jual beli lahan. Sewa menyewa dilakukan untuk lahan pertanian dengan sistem bagi hasil. Keluarga yang menyewa lahan membayar dengan hasil pertaniannya kepada pemilik lahan yang besarannya ditentukan dengan perjanjian pada awal menanam.
Bentuk perilaku pelestarian lingkung-an dan konservasi yang dilakukan oleh masyarakat Baduy, tercermin dalam kehidupan keseharian mereka. Praktik konservasi diwujudkan dalam hal:

1. Bagi masyarakat Baduy, hutan dianggap sakral sehingga masyarakat adat menghormati kawasan hutan mereka

2. Konsep pengelolaan lingkungan dengan sistem zonasi telah dikenal dan dipraktikkan masyarakat Baduy secara turun temurun. Sistem zonasi tersebut adalah: (a) Daerah Baduy Dalam analog dengan zona inti; (b) Daerah Baduy Luar analog dengan zona pemanfaatan intensif; dan (c) Daerah Dangka analog dengan zona penyangga, seperti Gambar 5 berikut.

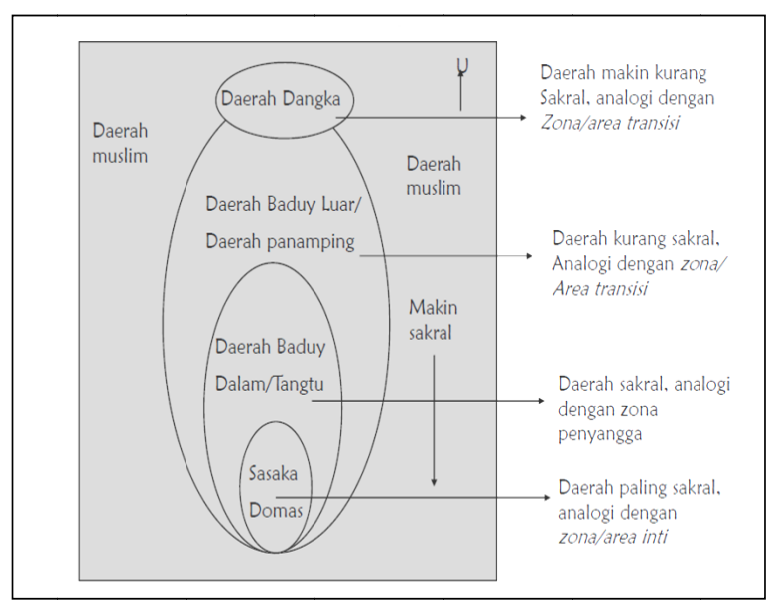

Gambar 6. Zonasi Praktik Konservasi Masyarakat Baduy

\section{SIMPULAN}

1. Adat, budaya, dan tradisi yang hidup di Baduy mudah dilihat dari tiga hal utama yang kental mewarnai keseharian mereka, yaitu sikap hidup sederhana, bersahabat dengan alam dan yang alami, dan spirit kemandirian. Ketiganya menyajikan variasi paduan yang menarik untuk disaksikan, ditelusuri, dan dinikmati. Sederhana dan kesederhanaan adalah titik pesona yang lekat pada identitas Baduy. Hingga saat ini masyarakat baduy berusaha tetap bertahan pada kesederhanaan di tengah arus "modernisasi" di segala segi. Bagi mereka kesederhanaan bukanlah kekurangan atau ketidakmam- 
puan, akan tetapi telah menjadi bagian tak terpisahkan dari arti kebahagiaan hidup sesungguhnya. Falsafah ini benarbenar mereka hayati dan jalani dengan penuh ketulusan dan kegembiraan.

2. Pada masyarakat Baduy yang hingga kini hidup dan menjalai kehidupannya secara bersahaja, tetap memegang kuat kepercayaan dan adat istiadatnya serta meniti hari demi hari dengan penuh kearifan. Kepercayaan dan adat istiadat itu menjadi pikukuh yang senantiasa menjadi falsafah hidup dan keseharian masyarakat Baduy. Nenek moyang atau leluhur Baduy melalui pikukuhnya mengajarkan bahwa berpikir, berkata, dan berbuat haruslah sesuai dengan aturan dan ketentuan yang telah ditetapkan. Aturan-aturan tersebut tidak boleh dikurangi atau ditambahi semaunya. Pikukuh itu juga mengajarkan kejujuran dan selalu menjaga kebenaran dan kebaikan untuk kemaslahatan dan keselamatan.

3. Pada hakikatnya kegiatan utama masyarakat Baduy adalah menyelamatkan dan menjaga tanah larangan yang telah dikeramatkan oleh leluhurnya. Oleh karena itu, perilaku masyarakat Baduy selalu diarahkan pada pengelolaan hutan dan lingkungannya dan pengelolaan lahan untuk kegiatan pertanian (ngahuma). Kegiatan pengelolaan lahannya dilakukan dengan menggunakan sistem padi kering yang lahannya di-bera-kan. Setiap tahapan perladangan diatur oleh ketentuan adat yang wajib ditaati seluruh masyarakat Baduy.

4. Bentuk perilaku pelestarian lingkungan dan konservasi yang dilakukan oleh masyarakat Baduy, antara lain meliputi: (a) sistem pertanian, (b) sistem pengetahuan, (c) sistem teknologi, dan (d) praktik konservasi. Kesemuanya itu dilakukan dengan mendasarkan pada ketentuan adat dan pikukuh yang telah tertanam dalam jiwa dan dilakukan dengan penuh kesadaran oleh seluruh anggota masyarakat Baduy.

\section{DAFTAR PUSTAKA}

Cecep Eka Permana. (2010). Kearifan lokal masyarakat Baduy dalam mitigasi bencana. Jakarta: Wedatama Widya Sastra

Erwinantu. (2010). Saba Baduy: Sebuah perjalanan wisata budaya inspiratif. Jakarta: Gramedia Pustaka Utama.

Feri Prihantoro, BINTARI Foundations. (2006). Kehidupan berkelanjutan masyarakat Baduy. Jakarta: Asia Good ESP Practice Project

Gunggung Seno Aji, (2010). "Kearifan lokal masyarakat Baduy dalam mengelola hutan dan lingkunyannya", Majalah $\mathrm{Hu}$ maniora. Volume 23, 1 Februari 2011 hal 14-25

Johan Iskandar. (1992). Ekologi perladangan di Indonesia: Studi kasus dari daerah Baduy, Banten Selatan, Jawa Barat. Jakarta: Djambatan.

Nababan, (1995). "Kearifan tradisional dan pelestarian lingkungan di Indonesia”.Jurnal Analisis CSIS: Kebudayaan, kearifan tradisional dan pelestarian lingkungan. Tahun XXIV No. 6 Tahun 1995.

Suhartini, (2009). "Kajian kearifan lokal masyarakat dalam pengelolaan sumberdaya alam dan lingkungan" Prosiding seminar nasional penelitian, pendidikan dan penerapan MIPA. Yogyakarta: Fakultas MIPA Universitas Negeri Yogyakarta. 